\title{
DE GRANADA A SEVILLA: ITINERARIO Y DESTINO DE LA MINORÍA MORISCA EN LA BÉTICA
}

\author{
Michel Boeglin*
}

En el marco de la política confesional de la monarquía, la cuestión morisca fue percibida como una excepción dentro de la homogeneización religiosa de la Península. El sublevamiento de las Alpujarras, más allá de una rebelión contra la autoridad real, suponía un rechazo de los valores de la sociedad cristianovieja que no había logrado crear un espacio para la integración del grupo mudéjar. La deportación de los "granadinos", llevada a cabo en 1570, no hizo sino desplazar el problema con todas sus dimensiones, políticas, sociales, económicas y culturales, conduciendo a las comunidades esparcidas en el suelo de Castilla a reorganizarse y a reconstituir su organización social, en medio de un nuevo entorno necesariamente marcado por conflictos de convivencia con las poblaciones locales.

Aunque Sevilla fue a la hora de la expulsión masiva de 1609 el núcleo de población castellana que acogía en su seno el mayor número de moriscos, carecemos aún de estudios de conjunto de esta minoría en la Bética ${ }^{1}$. La desapa-

* Universidad Montpellier III.

1. A pesar de la muy amplia y rica bibliografía sobre la cuestión morisca en España, Sevilla carece aún de monografía sobre la comunidad asentada en la urbe hispalense, aunque se trata de la ciudad de Castilla que contaba el mayor número de cristianos nuevos de moros a finales del siglo XVI. Fuera de los datos contenidos en las obras generales relativas a la historia de la capital andaluza, uno de los primeros estudios generales sobre el grupo morisco en Sevilla fue el de R. PIKE, «An urban minority: the moriscos of Seville», International Journal of Middle East Studies, 2 (1971), pp. 368-375, que proporcionaba numerosos datos sobre la demografía y la organización social de los moriscos en Sevilla, y el apartado dedicado a este grupo por la misma autora en Aristócratas y comerciantes: la sociedad sevillana en el siglo XVI, Barcelona, 1978 [1972 para la versión inglesa], pp. 167-181. Datos estadísticos en el momento de la expulsión pueden hallarse en M. SERRANO Y SANZ, «Nuevos datos sobre la expulsión de los moriscos andaluces», Revista contemporánea, tomo XC (1893), pp. 113-127. A.L. CoRTÉs PEÑA abordó cuestiones relativas a la integración de la minoría morisca en Sevilla en su artículo «Una consecuencia del exilio: los moriscos granadinos en Sevilla», en E. Belenguer Cebrià (ed.), Felipe II y el Mediterráneo, Madrid, 1999, pp. 537-552. Para la política de asimilación planeada y llevada a cabo por la Inquisición y las autoridades en Sevilla, véase M. BoEGLIN, L'Inquisition espagnole au lendemain du concile de Trente. Le tribunal du Saint-Office de Séville (1560-1700), Montpellier, 2003, pp. 233-279. 
rición de parte de los fondos del Archivo Municipal de Sevilla y la dispersión de los legajos relativos a la presencia morisca en Sevilla entre el Archivo Histórico Nacional para el aspecto inquisitorial y el de Simancas para la deportación de los granadinos, para lo esencial, explican el débil interés otorgado a este grupo en la rica historiografía de los últimos años. Esto, cuando la peculiar situación de Sevilla en la segunda mitad del siglo XVI hizo de la capital de la Bética el polo de atracción para numerosos grupos sociales y minorías socioculturales.

Sevilla, por su configuración excepcional -frontera del Imperio, ciudad que acababa precisamente su extraordinario desarrollo cuando se produjo la deportación-, presenció la llegada de un importante contingente de moriscos al final del año 1570. Diez años más tarde, en 1580, en la ciudad hispalense se hallaba la comunidad más importante de cristianos nuevos del reino castellano. La capital de la Bética se convirtió así en uno de los puntos neurálgicos donde la cuestión morisca se expresó con toda su complejidad: el número de cristianos nuevos originarios de Granada pasó de unas 2.000 personas oficialmente contabilizadas en 1571 hasta llegar a más de 7.500 a la hora de la expulsión de $1609^{2}$.

Nos encontramos con un grupo diseminado por la ciudad, concentrándose en las vecindades extramuros de Sevilla, extremadamente numeroso sin que las autoridades lograran o desearan vigilar la regularidad de esos asentamientos. Un importante dispositivo legal y sinodal pretendía controlar el devenir de la población y poner en marcha políticas para acelerar su asimilación a la sociedad cristiana. En las distintas disposiciones municipales, reales y sinodales, que se dictaron con motivo de la llegada de este nuevo contingente humano a Sevilla predominó, como en las demás ciudades castellanas, el aspecto represivo. El objetivo perseguido pretendía desarticular los núcleos de rebeldes y de creyentes que existían antes de la guerra de Granada y acabar con los rasgos distintivos de la identidad morisca. Ahora bien, la aplicación de dichas normas fue muy relativa, tanto por la falta de preparación del cabildo municipal como por la actitud ambigua de las autoridades con respecto a los miembros de la comunidad desplazada.

2. H. LAPEYRE, Géographie de l'Espagne morisque, París, 1959, pp. 150-151. Sobre los moriscos en la Península, véase A. Domínguez Ortiz y B. Vincent, Historia de los moriscos: vida y tragedia de una minoría, Madrid, 1979 y M. de EpAlzA, Los moriscos antes y después de la expulsión, Madrid, 1992 y M. García AREnAL, Los moriscos, Madrid, 1975. Sobre las comunidades moriscas en Castilla véase J. ARANDA DONCEL, Los moriscos en tierras de Córdoba, Córdoba, 1984; S. de TAPIA SÁNCHEZ, La comunidad morisca de Ávila, Salamanca, 1991; A. GARCíA LóPEZ, Moriscos en tierras de Uceda y Guadalajara, Madrid, 1992; J. FeRnÁNDEZ NIEVA, Los moriscos en Extremadura, 1570-1614: Aspectos demográficos, socioeconómicos y religiosos, Madrid, 1974, que completa oportunamente sobre ciertos puntos el artículo de M.A. HERNÁNDEZ BERMEJO, R. SÁNCHEZ RuBIO e I. TESTÓN Nuñez, «Los moriscos en Extremadura, 1570-1613», Studia historica. Historia Moderna, XIII (1995), pp. 89-118. 


\section{DEPORTACIÓN Y ASENTAMIENTO EN LA BÉTICA}

La cuestión morisca en Sevilla ganó su dimensión compleja y trágica al final de la guerra de Granada con la llegada de un contingente extremadamente elevado de moriscos. Los pocos documentos que certifican una presencia morisca previa al levantamiento de las Alpujarras dejan suponer que si existía una comunidad en Sevilla, ésta era reducida. Muy probablemente, los descendientes de mudéjares originarios de Sevilla se habían integrado en la sociedad cristiana y los nuevos convertidos que preocupaban a las autoridades eran esencialmente de condición servil y, por lo general, naturales de Granada ${ }^{3}$. En 1545, en uno de los mayores autos de fe de la primera mitad del siglo XVI en que salieron 65 condenados, comparecieron 17 moriscos con ocho esposas suyas, pero las únicas informaciones sociológicas que constan en la relación del auto de fe es que uno era alfarero y cuatro de ellos esclavos, sin mencionarse su procedencia geográfica ${ }^{4}$. Pero en los años que siguieron hasta la deportación de las Alpujarras, los acusados por mahometismo ante el Santo Oficio sevillano solían ser granadinos y, en su mayoría, esclavos: como Martín, juzgado en 1554 por haberse pasado "a Berbería y se tornó moro y de allí con otros moros hizo ciertas entradas en estas partes donde cautivaron y llevaron muchos cristianos" ${ }^{\prime \prime}$. Es más, un bando municipal que se dictó en Sevilla el 4 de noviembre de 1569 sobre "negros y negras y moriscos y moriscas que son esclavos y esclavas cautivas" confirma que la preocupación esencial de las autoridades se centraba en la población morisca de condición servil que, por lo general, era de origen granadino ${ }^{6}$.

3. Cf. M.A. LAdero Quesada, Los mudéjares en Castilla en tiempo de Isabel I, Valladolid, 1969, pp. 17-21. Ver también los interesantes aportes de K. WAGner, Regesto de documentos del Archivo de Protocolos de Sevilla referentes a judios y moros, Sevilla, 1978 y del mismo, «Un padrón desconocido de los mudéjares de Sevilla y la expulsión de 1502», Al-Andalus, 36 (1971). En la correspondencia administrativa del Santo Oficio sevillano, a partir de los años 1560, la proporción de moriscos antiguos entre los acusados es particularmente baja.

4. A.H.N. Inq., Lib. 785, $\mathrm{f}^{\circ}$ 227. También pueden hallarse datos acerca de secuestros a moriscos en A.H.N. Inq., leg. 4683 en los años 1540-1545, poco acomodados y por lo general originarios de Arcos.

5. A.H.N. Inq., leg. 2942 exp. 21-1.

6. Archivo Municipal de Sevilla (A.M.S.) Sección XVI, Varios Antiguos, exp. 328 (46), f $\mathrm{f}^{\circ}$ 2: esta normativa pretendía prohibirles el acceso a bodegones y tabernas a los esclavos negros, mulatos y moriscos, para que no dilapidaran la hacienda de sus amos emborrachándose. Según Celestino López Martínez, seguido por historiadores posteriores, esta ordenanza municipal tenía un alcance más general destinado a mantener el orden público, lo cual demostraría la existencia de un importante grupo de moriscos asentado en Sevilla ya en aquellos años. Véase C. López MArtínez, Mudéjares y Moriscos sevillanos, Sevilla, 1993 [1935], p. 68. Sin embargo, el objeto del documento son los esclavos y no los moriscos como grupo social específico y en ningún caso permite inferir un peso demográfico específico de los cristianos nuevos de moros en Sevilla antes de 1570. De hecho, estas prohibiciones tocantes a esclavos se dictaron en distintas ciudades castellanas en la segunda mitad del siglo XVI. 
Al finalizar la guerra de las Alpujarras fue cuando empezaron a producirse deportaciones en número creciente hacia la llanura del Guadalquivir. Desde el mes de febrero de 1570, Felipe II autorizaba que los "moriscos de paz" procedentes de Granada, Guadix y Baza pudiesen salir hacia Castilla con sus mujeres, niños y pertenencias ${ }^{7}$. El 20 de mayo de 1570, don Juan de Austria ordenaba desplazar a veinte familias ya deportadas a Sevilla hacia la capital del condado de Priego, probablemente por motivos de seguridad, lo cual sugiere que ya se hallaba en la capital hispalense cierto número de moriscos granadinos ${ }^{8}$. Pero la llegada en masa a Sevilla de los cristianos nuevos de moros se produjo sólo unos cuantos meses más tarde, como en el resto de las ciudades castellanas.

El proyecto de diseminar a los moriscos a través de Castilla había sufrido demoras a causa de la situación en el teatro de operaciones de la Sierra de Granada; pero a medida que la victoria en la guerra comenzaba a inclinarse a favor del ejército al mando de don Juan de Austria, volvió a debatirse el proyecto de dispersión de los descendientes de los últimos mudéjares. El grueso de las operaciones de guerra había finalizado en junio de 1570 en el antiguo Reino de Granada. Los pocos focos de resistencia estaban aislados en zonas remotas y ya no constituían una amenaza para la salida del conflicto. Entonces fue cuando se organizaron los preparativos: el traslado debía realizarse a toda costa antes del invierno, que amenazaba ser inclemente. El $1^{\circ}$ de noviembre llegaron las órdenes. Todo debía estar finalizado cuanto antes ${ }^{9}$.

La operación había alcanzado tales proporciones que apenas los oficiales de la Corona tuvieron tiempo para avisar a las autoridades locales de la salida de Granada de estos grupos. Se supone que entre 55.000 y 60.000 moriscos fueron desplazados hacia las tierras castellanas antes de finales del mes de diciembre de 1570, con toda la prisa y confusión que puede imaginarse ${ }^{10}$. En Sevilla, el 29 de noviembre de 1570, atracaban 24 galeras en el Arenal con el principal y probablemente único grupo de moriscos deportados directamente hacia la ciudad ${ }^{11}$. Esta llegada repentina cogió desprevenidas a las autoridades locales: don San-

7. B. VinCENT, «L'expulsion des morisques du Royaume de Grenade et leur répartition en Castille (1570-1571)», Mélanges de la Casa de Velázquez, tomo VI (1970), pp. 211-246, 217.

8. Véase A.L. CoRTÉs PEÑA, «Una consecuencia del exilio...», p. 539.

9. B. ViNCENT, «L'expulsion des...», pp. 214-215. Ver también del mismo, Andalucía en la edad moderna: economía y sociedad, Granada, 1985, pp. 230 y 242.

10. H. LAPEYre, Géographie..., p. 125 y A. DOMínguez ORTIZ, «Los moriscos granadinos antes de su definitiva expulsión», Miscelánea de Estudios Árabes y Hebraicos, XII/ XIII (1963-1964), pp. 113$128,117$.

11. A.G.S. Cám. Cast., leg. 2157, f ${ }^{\circ}$ 81: el Conde de Priego al Rey, 15.12.1570. Véase el apéndice 1: La fecha del 27 de noviembre evocada dos semanas después por el asistente es errónea; otros documentos más fidedignos indican el 29 como fecha de la llegada (ibídem $\mathrm{f}^{\circ}$ 82). Ningún documento posterior del fondo Cámara de Castilla o Estado del Archivo General de Simancas señala nuevos envíos masivos de deportados para Sevilla fuera de algunas reafectaciones a finales de los años 1570 de los moriscos que se encontraban en las zonas del litoral y en ciertos señoríos. 
cho de Leiva, el capitán de las galeras, entregó su mercancía humana a las autoridades de Sevilla pero sin ser capaz de indicar el número de deportados ni tener en su poder despacho real alguno que señalase a qué estarían destinados.

A la espera del despacho de un correo real, el asistente de la ciudad, el conde de Priego, adoptó las primeras medidas cautelares que se imponían frente al estado pésimo en que se encontraba gran parte de los deportados. Éstos, según el magistrado, estaban

“tan destrozados y pobres y robados y enfermos que fue gran compasión, y los que no lo venían, tan flacos y hambrientos que, visto que morían muchos y padecían tanta necesidad sin poder bastar las limosnas que se les dan de mala gana, me pareció, por ser tanta gente y tener tan mal aparejo, de remediarlo... poniendo los que se pudieren con amos y los enfermos a los hospitales, así por su sustentación y reparo como por entender que dividiéndolos serían más aprovechados, a lo menos los niños, para la instrucción de la fe" f $^{\prime 2}$.

El efecto desastroso de la guerra y las privaciones sufridas, en una zona devastada por dos años de hostilidades, habían debilitado sensiblemente a la población granadina. Las condiciones de la travesía y el tratamiento usualmente reservado a los derrotados hicieron el resto.

Los mismos sevillanos observaban con desconfianza la llegada de estos vencidos muchas veces considerados como "rebeldes". Como lo indicaba la carta del magistrado, difícilmente se lograba recaudar limosna para asegurar el mantenimiento de los necesitados. Tentativas de oponerse violentamente a la instalación del grupo se dieron, señal del profundo odio manifestado para con esta población temida y sospechosa de alevosía. Frente a estos moriscos que habían aparecido tan repentinamente y que ensancharían las filas de miserables que poblaban las calles de la capital de la Bética, algunos sevillanos protestaron, acometieron a varios deportados y procuraron echarlos al Guadalquivir ${ }^{13}$. Tanto fue así que los padres jesuitas tuvieron que intervenir ante las autoridades para que defendieran a los moriscos, instalados en adelante en un hospital en Triana y protegidos de las exacciones de la plebe ${ }^{14}$.

Con el fin de proporcionar el alojamiento de una parte -al menos- del contingente y a la espera de las disposiciones del Consejo de Castilla, las autoridades sevillanas decretaron, el mismo 29 de noviembre de 1570, las normas para su distribución entre los habitantes de Sevilla y de las zonas circundantes ${ }^{15}$. De entrada, los moriscos más sanos se colocaron bajo la tutela de un

12. A.G.S. Cám. Cast., leg. 2157, fo 81: el conde de Priego al rey, 15/12/1570.

13. M. de RoA, Historia de la Provincia de Andalucía de la Compañía de Jesús (1553-1662), en A. MARTíN Pradas e I. CARrasco Gómez (eds.), Écija, 2005, p. 198.

14. A.G.S. Cám. Cast., leg. 2157, f ${ }^{\circ} 81$.

15. A.G.S. Cám. Cast., leg. 2157, f82: Capítulo y orden del 29/11/1570. 
posadero, a quien incumbía supervisarlos, hacerlos trabajar y velar por su conversión. Los anfitriones habían de ser vecinos de Sevilla y "abonados" es decir de buena moralidad. Los cristianos viejos elegidos tenían la obligación de tratarlos correctamente, educarlos en la fe cristiana así como "ponerlos en buenas costumbres". Se comprometían, además, a ponerlos a disposición de las autoridades civiles en cuanto se manifestara tal voluntad ${ }^{16}$.

Según la disposición municipal, en ningún caso los núcleos familiares habían de ser separados contra su voluntad pero todos los niños de pecho debían obligatoriamente ser bautizados. La responsabilidad del cumplimiento de dicha obligación recaía en el posadero, quien tenía que conservar el acta que confirmara la administración del primer sacramento. La medida apenas debió de ser efectiva, puesto que el 8 de diciembre, apenas una semana después de la llegada de los moriscos, una nueva orden municipal reclamaba que todo aquél que viviera en Sevilla y tuviera un niño morisco bajo su custodia se presentara delante de las autoridades con dicho certificado para que se adoptasen las medidas que se imponían, sin más especificaciones. En aquella ocasión, se recordaba que le tocaba al amo bautizar a estos niños menores de dos años ${ }^{17}$.

El estatuto y el destino de estos moriscos recién llegados seguía siendo incierto. El alojamiento proporcionado por los habitantes de la ciudad tenía por contrapartida la obligación de servir a los posaderos. Pero para prevenir los posibles conflictos con los nuevos dueños otra orden ofrecía a los moriscos la opcción de presentarse ante los funcionarios de justicia para que fueran asignados a otras personas. Los deportados no eran considerados como esclavos; estaban más bien regidos por un sistema cercano a la encomienda medieval, en que, como contrapartida al mantenimiento y la educación religiosa, correspondía un servicio laboral, no remunerado, prestado al amo. Para despejar cualquier duda al respecto y evitar que se extendiera un lucroso tráfico humano, se pregonó que cualquier venta de moriscos de la guerra de Granada o Ronda quedaba tajantemente prohibida, so pena de degradación de oficio y confiscación de todos los bienes para el notario que estableciera el acta ${ }^{18}$.

Al día siguiente, el 30 de noviembre de 1570, se nombraba a dos diputados entre los veinticuatros, Melchor de Alcázar y Gaspar Ruiz de Montoya, a fin de proceder a la distribución de los moriscos entre los sevillanos, concediéndose cédulas a éstos y elaborándose la lista de los deportados. Hasta entonces habían sido alojados en su mayoría entre Triana, San Bernardo y el Mesón de los Carros. Al final del día, resultaba que numerosos deportados habían sido retirados o apartados de su lugar previo de alojamiento, sin que fueran informadas las au-

\footnotetext{
16. Ibídem.

17. Ibídem, Capítulo y orden del 8/12/1570.

18. Ibídem, Capítulo y orden del 29/11/1570.
} 
toridades. Por adición, todo parece indicar que, aprovechando la desorganización que presidía a su distribución, numerosos moriscos habían esperado la noche para huir de la ciudad o fundirse entre la masa anónima de la población. Poco después, pregones anunciaron por toda la ciudad que se condenaría a muerte a todo morisco que saliese de Sevilla sin despacho ni autorización ${ }^{19}$.

Tan caótica como su recepción, la distribución de los moriscos entre los habitantes de Sevilla se había realizado con el mayor desorden. Tres días después de su llegada, un edicto leído en los lugares más concurridos de la ciudad pedía, bajo pena de confiscación de los bienes, a toda persona que tuviera a su cargo uno o más moriscos sin licencia de los funcionarios de justicia, que se presentara ante éstos ${ }^{20}$. De forma más sorprendente, el mismo edicto indicaba que las personas que ya habían obtenido licencias para acoger moriscos debían también acudir ante las autoridades, con el fin de especificar el número de individuos que habían recibido o indicar los que habían huido o muerto...

La confusión parecía haber alcanzado su máximo grado. Se ignoraba el número exacto de deportados y dónde se encontraban muchos. Las listas ya elaboradas eran incompletas o inexistentes, cuando las disposiciones decretadas tenían por objeto evitar la dispersión de este grupo y las fugas, a la espera de una decisión real a su respecto. Sólo al cuarto día de la llegada de los moriscos, es decir el $1^{\circ}$ de diciembre, se intentó realizar un primer recuento. Según las actas de los funcionarios reales, "parece que" unos 4.300 individuos habían desembarcado de las galeras de Sancho de Leiva, incluyendo en esta partida a hombres, mujeres y niños ${ }^{21}$. La anterior acta municipal del 29 de noviembre de 1570, que registraba la llegada de la población desplazada, sólo indicaba "cierta cantidad de moriscos ${ }^{22 "}$, expresión que daba prueba de la imprecisión en cuanto al número exacto de deportados.

Según las cifras manejadas por Bernard Vincent, 5.500 moriscos habían embarcado para Sevilla, lo que representa 1.200 personas más de las que se contabilizaron a su llegada a Sevilla el 29 de noviembre ${ }^{23}$. Bien es cierto que la diferencia puede atribuirse a un naufragio, certificado, de varias galeras ocurrido frente a la costa almeriense, durante una tormenta que estalló poco después del principio de la deportación. Puede asimismo achacarse a una elevada tasa de mortalidad durante la travesía, habida cuenta del pésimo estado de los moriscos a su llegada. Pero también es muy probable que en espacio de tres días -del 29 de noviembre al $1^{\circ}$ de diciembre- una parte de estos moriscos

19. Ibídem, Pregón del 1/12/1570.

20. Ibídem, Auto del 30/11/1570.

21. Ibídem, Auto del 1/12/1570.

22. Ibídem, Auto del 29/11/1570.

23. B. VINCENT, «L'expulsion des morisques du Royaume de Grenade...», p. 221. 
hubiera optado por huir y que otros fueran raptados por cristianos viejos para su servicio doméstico o para ser vendidos como esclavos, como lo dejan entender documentos posteriores. Poco importaba en definitiva para las autoridades y éstas, en su correspondencia con el Consejo de Castilla, seguirían ateniéndose a la cifra de 4.300 personas desembarcadas.

\section{DISEMINACIÓN Y CONTROL DE LOS “REBELADOS"}

Finalmente, el 3 de diciembre comenzaba el plan de diseminación de los moriscos a través de las tierras de la jurisdicción de Sevilla ${ }^{24}$. Convenía reducir la concentración excesiva de "rebeldes" por motivos de seguridad pero probablemente también por razones de sanidad, ante los probables riesgos de "contagio" entre la población desvalida: el año 1570 había sido poco fértil y el asistente, el conde de Priego, decidió "dar algunas casas de ellos a algunas personas para sus heredamientos y a otras para poblaciones a algunos lugarejos cercanos a esta ciudad y con esto me parece se ha esparcido mucha cantidad de ellos ${ }^{25 \prime}$. Envió a unas 450 familias a Fregenal, Aracena, Cazalla de la Sierra, Constantina, Alanis y El Pedroso, lo que representaba un total de 1.233 personas, más de un cuarto de los deportados contabilizados a su llegada. Por otra parte, en dicha fecha, ya se habían distribuido 908 moriscos a posaderos de la capital para que "fueran administrados" por éstos.

Una epidemia se declaró entonces entre la población recién llegada a Sevilla. El 9 de diciembre de 1570, se pedía que los curas de las parroquias donde se había asignado residencia a los moriscos, es decir San Bernardo y Triana, procedieran a una estimación de las personas difuntas y enfermas. Según los informes, se desprendía que las enfermedades habían diezmado a la población desplazada: los muertos alcanzaban una cifra de "hasta 400 moriscos más o menos" sobre los 4.300 moriscos oficialmente desembarcados ${ }^{26} \mathrm{y}$ otros 450 moriscos estaban ingresados en los diversos hospitales de la ciudad.

En dicha fecha del 9 de diciembre, el asistente debía reconocer que no se había registrado a numerosos deportados, "ni se sabe quién[es] son, ni el número dellos y se andan escondiendo sin usar oficios ni servir amos y se han salido de las partes y lugares donde estavan recogidos en Triana y en el barrio de San Bernardo y el Mesón de los Carros"27. Al día siguiente, el domingo al mediodía, todos los moriscos granadinos fueron reunidos para un nuevo censo, con la esperanza de contabilizar a los que hasta entonces habían escapado a los padrones.

24. A.G.S. Cám. Cast., leg. 2157, f 81: Carta del asistente al rey del 15/12/1570; véase el apéndice 1.

25. Ibídem.

26. A.G.S. Cám. Cast., leg. 2157 , fo 82 , auto del 9/12/1570.

27. Ibídem. 
Se desprendía que 1.273 se hallaban en la urbe hispalense, incluidos los que estaban sanos o enfermos, de cualquier edad o condición, con 1.118 alojados en Triana y 155 en San Bernardo, barrio extramuros de Sevilla ${ }^{28}$. Es decir, de las distintas cifras barajadas, se conocía el rastro de alrededor de 3.300 moriscos, entre las personas colocadas en familias o bajo la custodia de las autoridades en Sevilla y sus tierras, aquéllas atendidas en hospitales además de los muertos. Las cuentas no salían: faltaban en los censos varias centenas de deportados, cuyo paradero se desconocía. Algunos habían huido, pero la sucesión de edictos que ordenaban que los moriscos adquiridos ilegalmente fueran entregados a las autoridades deja suponer que varios de ellos seguían estando en poder de cristianos viejos. Posteriormente, acusaciones de haberse trocado cédulas reales recayeron en oficiales, en particular en el teniente del asistente, el licenciado Valera, aunque éste negó cualquier responsabilidad en estos ye$\operatorname{rros}^{29}$. De entrada, el morisco deportado, víctima del recelo de la plebe, era al mismo tiempo el objeto del encarecido interés de ciertas categorías sociales por la fuerza de trabajo que representaba y pasó a ser un lucrativo objeto de tráfico.

El estado de salud de la población desplazada seguía crítico. El 2 de enero de 1571, un mes después de la llegada de las galeras, el informe al rey del licenciado Valera daba cuenta de los estragos dramáticos de la epidemia, de tifus probablemente, que se había declarado entre convalecientes y se había extendido a una parte de la población sevillana:

"de los que aquí quedaron se pusieron con amos así labradores como oficiales y ciudadanos mil y seiscientos para que los doctrinasen y trabajasen en sus oficios en esta ciudad y en algunos lugares comarcanos de ella. Todos los restantes quedaron enfermos de modorra y tabardetes y otras enfermedades muy malas que se comenzaron a pegar a los vecinos de esta ciudad con tanta furia que fue necesario para atajar tan grande mal, con consulta y parecer de médicos, que se sacasen luego a curar fuera de esta ciudad. Y así se hizo por orden de ella y del Asistente y se pusieron en un hospital donde hay hoy curándose seiscientos enfermos, sin otros más de cuatrocientos que están repartidos por la misma orden en otros hospitales y se les dan las medicinas y mantenimientos necesarios. Tiénese por cierto, según la información que se ha hecho por las collaciones que son muertos aquí más de los mil de ellos y muy gran parte de los que se llevaron fuera, y de cada día se van muriendo y parece que, entre sanos y enfermos, están en esta ciudad hasta mil y seiscientos con mucho trabajo y pobreza. Y así, por esto como por sus enfermedades, no se podrán sacar de donde están hasta que convalezcan ni se puede tener certidumbre de los que quedarán vivos y libres de las enfermedades que tienen, que cuando lo estén se podrán repartir algunos de ellos por las collaciones de esta ciudad

28. A.G.S. Cám. Cast., leg. 2157, fo 82.

29. A.G.S. Cám. Cast., leg. 2159, Carta del Licenciado Valera del 18/6/1571. 
[...] y los demás por los otros lugares de ella, adonde no se han llevado, que serán más de cincuenta" ${ }^{30}$.

El debilitamiento de la población desplazada era extremo y se puede evaluar, a partir de este testimonio, la tasa de mortalidad en un total del $25 \%$ sobre el número de los deportados en espacio de un mes.

En la primavera de 1571, la población oficialmente registrada en la jurisdicción sevillana se situaba en 2.860 moriscos, la mayoría distribuyéndose entre San Bernardo (260 individuos) y el municipio de Triana, donde residían 1.494 de ellos; el resto constituía pequeñas comunidades de 40 a 150 individuos, esparcidas en los pueblos del término de la capital hispalense ${ }^{31}$. De los 4.300 oficialmente registrados a su llegada, sólo quedaban vivos o identificados 2.860; el resto, como lo asentaba el licenciado Valera, "los que faltan son muertos y faltan del número que se registró de todos los moriscos que vinieron a esta ciudad" 32 . En definitiva, podemos basarnos en que la capital contaba con una comunidad "oficial" de unas 2.000 personas entre la ciudad de Sevilla y Triana, teniendo en cuenta a los moriscos ya presentes antes de la deportación y a los que tenían interés en escapar al censo: un documento diez años más tarde avanzaba la cifra de 2.159 moriscos quedados en Sevilla y Triana después de la deportación ${ }^{33}$.

En víspera del verano de 1571, la situación no dejaba de ser crítica. Según el licenciado Valera, si muchos moriscos habían sido entregados a familias sevillanas para el servicio doméstico o a artesanos para labores de diversa índole, la situación de la mayoría era pésima: "los moriscos que están en esta ciudad y su tierra de los que han quedado vivos, por la mayor parte están muy enfermos y pobres y la mayor parte de ellos andan a pedir por amor de Dios de puerta en puerta sin poder servir ni trabajar por su flaqueza y enfermedad" 34 . Se comprende, desde tales condiciones, que las autoridades no insistieran en recibir nuevos grupos de moriscos, que en adelante llegaron por pequeños grupos o individualmente, aunque de forma ininterrumpida.

De la llegada masiva de "rebeldes" granadinos a finales de noviembre de 1570, se destacaba, por tanto, la falta de preparación extrema de las autoridades y el estado lamentable de la población deportada como lo recalcaba el informe del asistente, forzado a reconocer que "ha sido la cosa de mayor confusión del mundo y compasión" ${ }^{35}$. En semejante contexto no es difícil imaginar que numerosas familias nucleares hubieran sido separadas ya antes de em-

30. A.G.S. Cám. Cast., leg. 2159, f 2, Carta del Licenciado Valera del 2/1/1571, véase el apéndice 2.

31. A.G.S. Cám. Cast., leg. 2162, f ${ }^{\circ}$ 64: Relación de los moriscos que hay en Sevilla y su tierra, 9/4/1571. Véase el apéndice 3.

32. Ibídem.

33. Véase el apéndice 5.

34. A.G.S. Cám. Cast., leg. 2159, fo 79-80, carta al rey del 18/6/1571.

35. A.G.S. Cám. Cast., leg. 2157, fo 77, carta al rey del 12/12/1570. 
barcar, y luego, cuando se repartieron los moriscos entre las distintas familias sevillanas, a pesar de las prohibiciones dictadas a este respecto. No obstante, a pesar del estricto control que pretendían llevar a cabo las autoridades, el número de moriscos aumentó vertiginosamente en los años posteriores, debido en parte al éxodo de los deportados que abandonaron las ciudades y pueblos circundantes de Sevilla, como lo muestra el caso de Carmona.

\section{LOS MORISCOS EN CARMONA}

Carmona, localidad distante ocho leguas de Sevilla y situada en el eje que unía a ésta con Córdoba, fue solicitada continuamente a lo largo de los años 1570 y 1571 para acoger a moriscos deportados. El 23 de enero de 1571, el corregidor de Carmona, el doctor de Aliaga, estimaba que los moriscos en Carmona representaban aproximadamente unas 270 casas pobladas tras un primer censo nominal de todos los moriscos asentados en la dicha villa. Por lo tanto, se puede estimar en unos 600 ó 700 el número de moriscos asentados en la villa de Carmona, que contaba entonces con 3.000 habitantes ${ }^{36}$.

Una tentativa de recuento de las principales llegadas de moriscos a Carmona, realizado en agosto de 1571, a instancias del nuevo corregidor entrado en funciones, el licenciado Gutiérrez de Mayorga, permite seguir el rastro de parte de la población deportada. Como en Sevilla o en Écija ${ }^{37}$, las primeras llegadas se registraban a partir de la primavera de 1570. El 2 de mayo de 1570, 196 moriscos procedentes de Toloj se deportaban hacia Carmona en condiciones pésimas, pues de éstos murieron $62^{38}$. Si se añaden las defecciones, fueron en definitiva 128 moriscos quienes quedaron en dicha villa. Once huérfanos procedentes de Ronda fueron entregados a lugareños el mismo día. Dos días más tarde, el 4 de mayo, 33 moriscos llegaban de la provincia de Córdoba; seis murieron en los días siguientes y catorce de ellos huyeron. El mismo día, otro convoy con once moriscos llegó a Carmona. Una comunidad de unos 140 moriscos debía de encontrarse entonces registrada en dicha villa. No obstante, siguieron produciéndose otras entregas al año siguiente: el 29 de enero de 1571, el corregidor de Carmona recibía a 44 moriscos procedentes de Toloj y de éstos siete fallecieron. El 9 de febrero, 29 moriscos de Ronda y Bentomiz se asentaron en la dicha villa y en la semana tres de ellos huyeron ${ }^{39}$.

36. A.G.S. Cám. Cast., leg. 2159, f ${ }^{\circ} 22-23$, carta del 23/1/1571. Unas cifras muy superiores al descuento que encargaría unos meses más tarde, en agosto de 1571, el nuevo corregidor entrado en funciones, el licenciado Gutiérrez de Mayorga.

37. J. ARANDA DONCEl y M. MARTín OJEDA, «Evolución demográfica y estructura de la población morisca en la ciudad de Écija», Écija en la Edad Media y el Renacimiento, Actas del III Congreso de Historia (1991), Sevilla, 1993, pp. 227-251.

38. A.G.S. Cám. Cast., leg. 2163, f ${ }^{\circ}$ 57-59, carta del 27/8/1571.

39. Ibídem. 
Resulta claro, a la vista de estos datos, que los desplazamientos de moriscos de Granada y Ronda habían empezado ya antes de la expulsión masiva de finales del año 1570. Desde la primavera de dicho año, cientos de moriscos eran enviados, por vía de tierra, hacia Écija, Sevilla, Carmona y las otras ciudades andaluzas. Como en Sevilla, el número de defunciones fue extremadamente elevado, pues se registra en Carmona una tasa de mortalidad de un $25 \%$ (76 muertos de los 284 moriscos entregados a la autoridades de la ciudad entre el mes de mayo de 1570 y el de 1571). Por fin, se notará el fuerte índice de huidas entre estos moriscos: de los 150 moriscos registrados por el licenciado Gutiérrez de Mayorga en agosto de 1571, más de un 40\% había escapado sin licencia real, señal de la dificultad de las autoridades locales para vigilar a los desplazados. Un fenómeno que debió de producirse en numerosas otras localidades y que puede explicarse por la dramática situación por la que pasaba la comunidad desplazada en Carmona y en villas semejantes.

En un primer momento, en enero, el tono del doctor de Aliaga era entusiasta con la perspectiva de diseminar a los deportados granadinos en las aldeas circundantes. Para el corregidor, se podían repartir por los lugares de Mairena, Guadajoz, Fuentes, Tocina y otras poblaciones de la jurisdicción de Carmona adonde ningún morisco aún no había sido enviado. Allí "podrán sustentarse y vivir en los lugares como los demás vecinos pobres de ellos, sirviendo o cogiéndose para las dichas labores y tratos del campo y para que éstos estuviesen divididos y no se ausentasen a otras partes ni fuesen a vivir a otros lugares me parece, siendo Vuestra Majestad de ello servido, que sería bien repartir a los dichos moriscos en todos estos lugares" ${ }^{\prime 40}$. Ahora bien, se trataba de zonas agrícolas, tierras de pan sembrar, olivares y algunas viñas. Aunque fértil, la tierra era tan seca que la producción de las huertas ocupaba un peso poco importante. Pero sólo en los trabajos de la tierra podían encontrar los moriscos alguna posibilidad de sustento, en ausencia de verdadera especialización manufacturera de la villa. El proyecto del doctor de Aliaga era, pues, repoblar estas tierras y ponerlas en valor.

Siete meses más tarde, cuando el licenciado Gutiérrez de Mayorga había entrado en funciones en Carmona, la percepción de la situación era sensiblemente menos entusiasta. Acogía, por orden de don Juan de Austria, a unos 150 moriscos el 15 de julio de 1571, además de unos once que se presentaron por su propia iniciativa. Pero las autoridades no tenían ninguna posibilidad de asignarles un oficio y aún menos de entregarles tierras ${ }^{41}$. Sobre todo, en su informe, el nuevo corregidor señalaba que muchos de los moriscos eran tan viejos que no podían trabajar y pasaban hambre. En cuanto a los demás, una vez acabada la cosecha de las aceitunas no tenían modo alguno de ganar su sustento. El silencio de las primeras disposiciones reales sobre posibles licencias

40. A.G.S. Cám. Cast., leg. 2159, f ${ }^{\circ} 22$, carta del 23/1/1571.

41. A.G.S. Cám. Cast., leg. 2163, f $57-59$, carta del 27/8/1571. 
que entregar a los moriscos para que pudiesen acudir a trabajar a otros lugares les obligaba a pasar largos periodos de privaciones, en particular en aquel año de 1571 de sequía particularmente grave. Debido a la falta de especialización manufacturera en dicha ciudad, más allá de los oficios mecánicos para satisfacer las necesidades de los lugareños, los desplazados se encontraban sin trabajo y sin posibilidad de cultivar tierras debido a la aridez del suelo. La única solución que contemplaba el magistrado era mandar parte de ellos a las huertas de la ribera del Guadalquivir; pero debido al riesgo de que bajaran el río para huir a Berbería, es poco probable que las autoridades reales apoyaran tal iniciativa ${ }^{42}$. Más de diez años más tarde, el corregidor de Carmona escribía a la Cámara de Castilla que "en esta villa hay muy pocos alistados y de estos se han muerto casi la tercia parte" ${ }^{\prime 3}$.

En semejantes condiciones, no es de extrañar que Sevilla apareciera como uno de los destinos naturales a la población morisca de las zonas circundantes e incluso de otras ciudades castellanas. En Sevilla se hallaban oportunidades de empleo, además de la posibilidad, para los huidizos, de pasar desapercibidos entre la masa de la población. Las autoridades, por lo demás, habían adoptado una actitud equívoca con respecto a los moriscos. Si el recelo y el rechazo popular se manifestaron contra los deportados desde el momento de su llegada y si la confusión había presidido a su repartición, el cabildo municipal parece haber hallado un interés notable en que los moriscos siguieran instalándose en los años siguientes. Las elites habían observado acaso con interés la llegada de moriscos durante toda la década de 1570, viendo en esta afluencia de una mano de obra a menudo especializada y poco vindicativa una contrapartida oportuna al encarecimiento de los costes de producción y a la despoblación de las zonas rurales, como se observó en otras partes de Castilla ${ }^{44}$.

\section{LA “DISIMULACIÓN" DE LAS AUTORIDADES}

En Sevilla, los moriscos disfrutaban de la protección de las autoridades. Sólo esto puede justificar el aumento notable de la población morisca, cuyo número hizo más que doblar en diez años. Es cierto que algunos desplazamientos posteriores de población tuvieron lugar, pero no bastan para explicar

42. A.G.S. Cám. Cast., leg. 2163, f 57-59: carta del corregidor de Carmona, el licenciado Gutiérrez de Mayorga, del 27 de agosto de 1571.

43. A.G.S. Cám. Cast., leg. 2184, carta del corregidor de Carmona al rey del 16 de abril de 1583.

44. Lo mismo se registra en Córdoba, J. ARANDA DONCEL, «Cristianos y moriscos en Córdoba: la actitud de las distintas capas sociales ante la presencia de la minoría disidente», Les morisques et leur temps, París, 1983, pp. 245-268. Véase también J. GIL SANJUÁN, «Presión material sobre los moriscos andaluces», Baetica, 3 (1980), pp. 188-197; S. de TAPIA, «La opresión fiscal de la minoría morisca en las ciudades castellanas: el caso de la ciudad de Ávila», Studia Historica. Historia Moderna, 4, 3 (1986), pp. 17-49. 
el prodigioso aumento de los moriscos en la capital hispalense. Así, en noviembre de 1571, una provisión del presidente de Granada exigía que fueran recogidos de Bornos "todos los moriscos libres que vivían en esta tierra y los enviase a Sevilla al Asistente de ella que tenía orden de recibirlo" ${ }^{\prime 5}$. Una medida similar se dictaba para las otras localidades en tierras de señorío que habían recibido a moriscos, en particular las poblaciones del litoral como Estepa u otras como Marchena, adoptadas por motivos de seguridad en un momento en que las costas aparecían poco seguras ${ }^{46}$.

No obstante, semejantes medidas que se renovaron en repetidas ocasiones no bastan para explicar el auge de la población morisca en Sevilla entre 1570 y 1580. En enero y abril de aquel año, los jurados de Sevilla se estremecían del elevado número de moriscos presentes en Sevilla y de su concentración masiva en ciertos barrios, reclamando que se realizaran censos como lo exigían las pragmáticas reales ${ }^{47}$. El 21 de junio, después de un rumor de rebelión de los moriscos de Sevilla en concertación con los de Córdoba y Écija, el asistente procedió a un censo nominativo, que parece haber sido el primero desde la llegada del contingente a finales del año $1570^{48}$.

Según el asistente en funciones en 1580, el conde del Villar, de los 4.300 moriscos desembarcados en 1570, sólo 2.159 se habían quedado en Sevilla y Triana, muchos de ellos enfermos. En el momento del nuevo padrón, diez años más tarde, 6.247 moriscos se hallaban en Sevilla sin que ningún otro convoy masivo de desplazados hubiese salido de Ronda o de Granada para la ciudad hispalense ${ }^{49}$. De los oficialmente registrados, 1.083 -el 17,3\%- eran esclavos y cautivos, a quienes no se aplicaban las prohibiciones tocantes a su residencia ${ }^{50}$. Por tanto, según las conclusiones del escribano, 3.005 moriscos más de la cuenta se hallaban en Sevilla, en violación de todos los bandos existentes. Aunque es de notar que este recuento rápido no tomaba en cuenta el traslado impuesto por el Consejo de Castilla y el Consejo de Guerra de aquellas familias mo-

45. A.G.S. Cám. Cast., leg. 2158.

46. A.G.S. Cám. Cast., leg. 2158, cartas del 11/12, del 16/12 y 20/12 de 1571. Sobre el miedo a las posibles conspiraciones, véase B. TAYLOR, «The enemy within and without: an anatomy of fear on the Spanish Mediterranean littoral», Fear in Early Modern society, Naphy W.G. and Roberts P. (eds.), Manchester, 1997, pp. 78-99.

47. A.M.S. Varios antiguos, $\mathrm{n}^{\circ} 334, \mathrm{f}^{\circ} 1$ y $2 \mathrm{r}-\mathrm{v}$.

48. Sobre este acontecimiento, véase B. VINCENT, «Les rumeurs de Séville», en D. PÉREZ SÁNCHEZ (coord.), Vivir el Siglo de Oro. Poder cultura e historia en la época moderna, Salamanca, pp. 165-177 y M. BoEGLIN, «Entre resistencia a la política de asimilación y afabulación: el "alzamiento" de los moriscos andaluces de 1580», en K. InGRAM (coord.), Actas del II Congreso The Conversos and Moriscos Within and Without Spain, Plasencia, 18-20 de mayo de 2005, Saint Louis University (en prensa).

49. A.G.S. Cons. Real, leg. 257, exp. 4, fo8-I. Véase el apéndice 5.

50. Ibídem. 
riscas desplazadas después de la deportación de 1570 hacia Sevilla para despoblar las zonas costeras o ciertos señoríos ${ }^{51}$.

Así y todo, estas cifras señalaban que Sevilla se había convertido en un polo de atracción para los moriscos que no hallaban trabajo en las zonas rurales ni acceso a la tierra, para los deportados en búsqueda de sustento o que deseaban pasar desapercibidos en la populosa urbe que era Sevilla. Sobre todo confirmaba lo que ya podían descubrir los sevillanos a diario: la concentración extremadamente elevada de moriscos en el municipio de Triana y en ciertos barrios como San Lorenzo, San Gil y Omnium Sanctorum así como en los arrabales extramuros, viviendo en corrales de vecindad, en contra de lo que preveían los bandos reales que ordenaban su dispersión entre los cristianos viejos para acelerar su conversión y forzar su asimilación. Una comunidad que representaba así entre un 6 y un 8\% de la población de Sevilla, que debía de contar entonces con unos cien mil habitantes.

Ante el estado calamitoso del grupo a su llegada no se puede conjeturar un crecimiento natural de la población morisca, muy al contrario. Diversos casos dejan entender que los moriscos asentados en Sevilla se beneficiaban del amparo de las autoridades, en contra de lo que preveían los bandos. En 1585, por ejemplo, un alguacil mayor de Ciudad Real, quien había acudido a Sevilla para detener a dos moriscos granadinos que se habían ausentado de su ciudad sin licencia real, se encontró en el banquillo, acusado de haber levantado falsos testimonios ${ }^{52}$. Los dos moriscos que se hallaban sin justificación alguna en Sevilla fueron liberados bajo fianza de la Cárcel Real y en ningún momento parece haberse evocado su transferencia hacia su primer lugar de destino. El caso fue posteriormente elevado ante el Consejo de Castilla. Este asunto deja entender el poco apresuramiento de las autoridades para dar ejecución a los edictos reales de 1572 y 1583, que preveían que los moriscos deportados debían permanecer en el lugar que se les había asignado. Poco tiempo después, el doctor Liébana, procurador de los moriscos, protestaba ante el rey de la falta de aplicación de las normativas relativas a dicha población y que los corregidores "disimulaban" con los moriscos, frenando la instrucción

51. En 1578, nuevas asignaciones de moriscos que estaban asentados en las costas tuvieron lugar y supusieron una nueva, aunque poco numerosa, afluencia de personas hacia las ciudades del interior y hacia Sevilla, elementos que omiten de señalar los jurados. Fue el caso de los moriscos procedentes de Gibraltar a petición del Consejo pero que serían desplazados sólo dos años más tarde (A.G.S. Cám. Cast., leg. 2181, carta del corregidor de Gibraltar al rey del 2/10/1578). El 11 de julio de 1580, en un despacho al Consejo Real el licenciado Morales señala, a propósito de Écija, que "habrá un año los del Consejo de Guerra que residen en la ciudad de Granada enviaron un juez pesquisidor para que sacase de aquí todos los moriscos y los llevase a Sevilla. El cual los sacó excepto los pocos que aquí quedaron por las diligencias que esta ciudad hizo para que quedasen algunos por la labor" (A.G.S. Cons. Real, 257 exp. 4, $\left.\mathrm{f}^{\circ} 8-\mathrm{I}\right)$.

52. A.G.S. Cám. Cast., leg. 2193, exp. s/n. 
de los procesos ${ }^{53}$. En 1608, aún, en vísperas de la expulsión masiva de los granadinos, el asistente de Sevilla, don Bernardino de Avellaneda, escribía al rey "por descargo nuestro, doy cuenta a Vuestra Merced... que los moriscos, que con tan conocido peligro se aumentan, a éstos dicha Audiencia los favorece contra las mismas cédulas que de Vuestra Merced hay" ${ }^{\prime 2}$.

Así, no es de extrañar que las autoridades sevillanas ocultaran el número creciente de moriscos presentes en la capital. A pesar de la insistencia de los consejeros del rey por conocer el peso demográfico de dicha minoría en las distintas ciudades castellanas, las autoridades eclesiásticas y seculares parecen haber manifestado poco interés en revelar el aumento preocupante del número de moriscos en la capital. En 1581, sólo dos ciudades no habían enviado al Consejo de Castilla los padrones de sus moriscos, Plasencia y Sevilla ${ }^{55}$. Dos años más tarde, en 1583, el asistente de Sevilla escribía al rey para garantizarle el cumplimiento de dicha medida, pero a diferencia de los otros corregidores del reino, no se entregó ningún censo o estimación ${ }^{56}$. Una actitud que revelaba el foso existente entre las disposiciones normativas relativas a los moriscos y su aplicación, a semejanza de lo ocurrido en otras ciudades castellanas.

\section{VIGILANCIA FÍSICA Y CRISTIANIZACIÓN: LA COLABORACIÓN DE LAS AUTORIDADES ESPIRITUALES CON EL PODER CIVIL}

Las disposiciones municipales decretadas el 29 de noviembre de 1570, a la llegada de los moriscos, habían seguido tres ejes: la vigilancia de los desplazamientos de los granadinos, la conversión, y la necesidad de destinarlos a un trabajo. Los edictos reales tomarían muy rápidamente el relevo, recabando estas tres líneas conductoras, reforzando al mismo tiempo el aspecto represivo, con el fin de romper la cohesión del grupo y acelerar la asimilación a la sociedad dominante. Muy atentas a esta política, aunarían sus fuerzas e influencia las autoridades episcopales, esperando que, así, la evangelización sería mas efectiva.

Como ya lo preveía el edicto municipal del 29 de noviembre de 1570, los moriscos asignados a posaderos, al igual que otros, se colocaron bajo la doble tutela de las autoridades civiles y de la Iglesia. El 6 de octubre de 1572, cerca de un

53. R.A.H. Secc. mss., leg. 9/6436, exp. s/n. Sobre la actuación del juez de comisión, Alonso de Liébana, véase A. GARCíA LÓPEZ, «Conflictividad y conciencia. La aplicación de la justicia y la minoría morisca en Castilla», en A. Mestre SANCHís y E. GiméNeZ LóPez (eds.), Disidencias y exilios en la España moderna, Alicante, 1997, pp. 455-468, 456-463.

54. A.G.S. Estado, leg. 210, carta a Su Majestad de don Bernardino de Avellaneda, del 19/8/1608.

55. A.G.S. Cám. Cast., leg. 2183.

56. A.G.S. Cám. Cast., leg. 2184, carta del conde de Villar del 3/3/1583. 
año después de la deportación, el Consejo de Castilla decretaba las principales medidas que regularían el destino de la minoría morisca. Por su parte, en Sevilla la jerarquía católica se limitó a cumplir, como en otras diócesis, la voluntad de Felipe II de acelerar la asimilación de este grupo sin aportar o proponer medidas de integración novedosas ${ }^{57}$. Los tres sínodos celebrados en Sevilla en 1572, en 1586 y luego en 1604 por los distintos prelados que se sucedieron no hicieron más que seguir las directrices reales, sin proponer nuevas soluciones tangibles a la suerte de esta minoría. Insistieron mayoritariamente en las medidas vinculantes necesarias para forzar y acelerar la conversión de aquella minoría ${ }^{58}$.

A pesar de la labor humanitaria desempeñada por ciertas órdenes como los jesuitas, la Iglesia aportó su apoyo a las autoridades civiles para controlar los desplazamientos y vencer las resistencias a la política de asimilación forzada. Conjugaron también sus esfuerzos para procurar suprimir los rasgos de pertenencia a la cultura morisca y facilitar, de esta forma, la evangelización del grupo. Sólo al destruir las solidaridades y al borrar las especificidades culturales de los deportados, podían las autoridades esperar facilitar una integración rápida de aquella minoría a la sociedad castellana.

Era necesario por todos los medios favorecer la dispersión de los núcleos moriscos. Si se había acordado que las familias de las personas que no habían tomado una parte activa en la guerra de Alpujarras no serían separadas, las primeras medidas pretendían lograr una importante dispersión de los moriscos, de tal modo que no se reconstituyeran núcleos de resistencia a la sociedad dominante. Apenas realizada la deportación, el 15 de diciembre de 1570, el rey pedía al asistente de Sevilla que distribuyera e instalara los hogares moriscos en las ciudades, pueblos y lugares "de estos nuestros reinos por menudos y apartados y divididos de manera que siendo posible no haya más de uno o dos en cada parroquia de cada pueblo o los que pareciere según la disposición y comodidad que hubiere en él" ${ }^{\prime 59}$. Un año más tarde, se relativizaba el alcance de dicha medida, irrealizable por cierto, y se reclamaba simplemente que "en los lugares más principales donde habrá más número de ellos no vivan juntos en un barrio sino en casas apartadas y que estén entre cristianos viejos dando asimismo orden que no vivan, ni estén, ni haya en una casa más de uno con su casa y familia"60.

57. J.M. MAGÁn GARCíA y R. SÁnCHEZ GONZÁLEZ, «Los nuevos convertidos del reino de Granada en las sinodales de las diócesis castellanas», en A. Mestre SANCHís y E. GiménEz López (eds.), Disidencias y exilios en la España moderna, Alicante, 1997, pp. 393-409.

58. Ya a la llegada del grupo deportado, el timorato clero sevillano se caracterizó por su desconfianza con respecto a los desplazados, negándose en un primer tiempo a absolver en el fuero interno a los granadinos por los crímenes de herejía pasados como lo había exigido el Consejo de la Suprema Inquisición: véase A.L. CORTÉS PEÑA, «Una consecuencia del exilio...», p. 542.

59. A.G.S. Cám. Cast., leg. 2159, fo 80, J. SENTAURENS, «Séville dans la seconde moitié du XVIe siècle», Bulletin Hispanique, 77 (1975), p. 375.

60. A.G.S. Cám. Cast., leg. 2196: La orden que se ha de tener para la vivienda de los moriscos del reino de Granada que se repartieron por estos reinos, Madrid a 6 de octubre de 1572, $\mathrm{f}^{\circ} \mathrm{s} / \mathrm{n}$. 
En este sentido, en Sevilla se distaba mucho de tal dispersión, ya que las parroquias de Triana y San Bernardo acogían la mayor parte de los moriscos. Los jurados y sacerdotes de Sevilla se prevalieron, en varias ocasiones, del edicto real; y en particular, a principios del año 1580, para protestar por la excesiva concentración de moriscos en sus barrios y el incremento de inseguridad, "los cuales tienen por costumbre de vivir en corrales y casas y otras partes juntos de tal manera que el menos número que se juntan de ellos más de veinte, los cuales viven con mucha libertad y desenvoltura de tal manera que ejercitan su ley, hablando su ley [sic], cantares y algazaras y viviendo libres sin servir a ningún señor ${ }^{61 "}$.

Para los jurados sólo la dispersión a través de hogares cristianos podía permitir la dilución de la identidad del grupo y facilitar un control mayor sobre los moriscos, que de esa forma ya no podrían practicar más sus ritos al amparo de las miradas exteriores. Aunque varios documentos confirman el cumplimiento más estricto de los edictos a partir de los años 1580, no es raro encontrar en la Sevilla de 1589, corrales de vecindad donde vivían juntos entre 20 y 30 moriscos y a veces hasta 90 personas.

La medida de diseminación de los granadinos a través del Reino se combinaba con las limitaciones a su libertad de movimiento. El edicto real de 1572 preveía que, en todo lugar, fuera cual fuera la jurisdicción imperante, debía realizarse un censo exhaustivo y extremadamente preciso de los moriscos ${ }^{62}$. Sacado en dos ejemplares por las autoridades de justicia, uno debía entregarse al obispo a fin que pudiera comunicarlo a los curas interesados; y otro al regidor al que se nombraría como superintendente de los moriscos. Esta medida de control fue completada por otros reglamentos drásticos que prohibían a los moriscos, bajo cualquier pretexto, trasladarse o pernoctar fuera de su lugar de residencia $^{63}$. Las personas deseosas de asentarse en una población diferente debían obtener la autorización del Consejo de Castilla y la del cura para mudarse de una parroquia a otra ${ }^{64}$.

Los sínodos prolongaron estas directivas haciendo de los sacerdotes asignados a los moriscos uno de los mecanismos esenciales del control de la población. Para ello, a partir de 1572, cada cura de parroquia debía conservar un padrón de todos los moriscos libres y esclavos, mujeres y niños, indicando su

61. A.M.S., Varios Antiguos, mss 334, fo 2r/v: cartas de los jurados del 20 de abril de 1580. Véase el apéndice 6. La emoción de los jurados y de la población es comprensible a la vista de la coyuntura crítica a principios de los años 1580, cuando aparece el hambre y los primeros brotes de peste en Sevilla y se están realizando los preparativos para la guerra de Portugal. Sobre este contexto específico anterior al presunto levantamiento de los moriscos de Sevilla véase M. BOEGLIN, «Entre resistencia a la política de asimilación y afabulación: el “alzamiento" de...».

62. A.G.S. Cám. Cast., leg. 2196: La orden que se ha de tener... ya citado.

63. Ibídem.

64. Ibidem. 
nombre y lugar de residencia precisa. Habida cuenta de la fuerte movilidad de los moriscos dentro del espacio urbano, se reclamaba en el sínodo siguiente de 1586 que las visitas se hicieran cada dos meses para que se tuviera conocimiento de las personas difuntas, de las que abandonaban la parroquia y de las recién llegadas ${ }^{65}$. Ese mismo año, con el fin de atenuar el número creciente del grupo granadino en Sevilla, se exigió que ningún morisco pudiera cambiar de parroquia sin haber recibido de antemano una cédula expedida por el párroco de su barrio. Ahora bien, entre las órdenes y su cumplimiento existía un foso insalvable y no sólo eran aproximativos los registros, sino que se establecían sólo una vez al año por Cuaresma y no cada dos meses como lo preveía el texto sinodal ${ }^{66}$.

Además de las listas de moriscos, los registros de bautismo eran de una importancia fundamental para seguir la evolución de la población. El arzobispo don Rodrigo de Castro, en 1586, impuso un control riguroso de los bautismos: cada niño bautizado debía estar inscrito sobre los registros; pero por añadidura debían mencionarse el nombre y sobre todo la condición de morisco libre o esclavo, so pena de excomunión principal y del pago de un ducado tomado a cada padre. Una medida recogida y reforzada en el sínodo siguiente, con una multa del mismo importe para los padres que no bautizaran a sus niños en el transcurso de ocho días desde su nacimiento ${ }^{67}$. El morisco debía así ser objeto de una observación escrupulosa que diera cuenta de los distintos accidentes de su existencia; desde el nacimiento hasta la muerte, instrumentos de control debían garantizar el seguimiento y la vigilancia de la población marginada.

La educación religiosa era, por fin, otro de los medios pretendidos por la Iglesia para apartar a los cristianos nuevos de la herejía y facilitar su cristianización. El vicario o el cura más viejo de la parroquia debía destinarles un lugar de culto, iglesia, ermita u hospital, donde los domingos y días festivos pudieran oír misa. En Sevilla y Triana, en 1589, se registran nueve lugares de culto destinados a la evangelización para una población de más de 6.300 moriscos. Desde aquellas condiciones, los efectos de la catequesis sólo podían ser limitados ${ }^{68}$. Se habían asignado clérigos y alguaciles específicos a la minoría, excepto para los lugares donde no se disponía de otro cura o religioso que pudiera llevar a cabo la educación religiosa de los moriscos; en éstos, se toleraba que los

65. Constituciones del Arzobispado de Sevilla hechas y ordenadas por el Ilustrísimo y Reverendísimo Sr Don Fernando Niño de Guevara... en la Sinodo que celebró en su catedral año de 1604..., 1609, Sevilla (reed.) 1862, 1864, 2 vols., Lib. I, cap. X, 55.

66. A.G.S Cám. Cast., leg. 2196, Padrón de los moriscos de Sevilla, parroquia de San Andrés, $\mathrm{f}^{\circ} \mathrm{s} / \mathrm{n}$.

67. Constituciones del arzobispado de Sevilla..., cap. XI, 57.

68. A.G.S. Cám. Cast., leg. 2196, fº s/n. En 1595, según F. de B. de MedinA, «La Compañía de Jesús y la minoría morisca (1545-1614)», Archioum Historicum Societatis Iesu, 57 (1988), p. 113, el número de lugares de culto bajó a siete. 
miembros de la minoría pudiesen asistir a misa con los cristianos viejos, con la condición de que el cura se informara de su conocimiento de la doctrina al final de la celebración religiosa. Habida cuenta de la recepción poco calurosa reservada a la minoría morisca a su llegada, no es sorprendente que los prelados hubieran decidido apartarlos en lugares de culto específicos, con el pretexto de adaptar la doctrina a su conocimiento religioso. Muy probablemente también se temían desórdenes durante la celebración de los oficios o conflictos que podían producirse entre cristianos viejos y nuevos. Esta discriminación, además, profundizaba aún más la división entre moriscos "antiguos" y los deportados granadinos pues sólo se aplicaban a éstos las medidas segregativas.

La ausencia de misa se sancionaba severamente mediante multas. El alguacil de los moriscos debía estar presente el domingo en la misa para supervisar a dichos individuos. Prueba del escaso efecto de esa medida en la asiduidad a la misa es que en el sínodo siguiente, celebrado bajo don Rodrigo de Castro en 1586, se establecía que no sólo los clérigos de los moriscos, sino también los alguaciles debían estar continuamente en posesión de la lista de los creyentes y castigar a los ausentes, con toda la publicidad requerida para escarmentar al público.

Destinados a ser objeto de una vigilancia constante por parte de los curas y de los alguaciles nombrados, en la práctica lograron zafarse de estas prescripciones si nos fiamos de un correo enviado al provisor del arzobispado de Sevilla, Luciano Negrón. Aunque se trate de una carta no firmada, enviada durante la vacante de la sede episcopal, da cuenta del foso existente entre las medidas dictadas y su ejecución y los casos continuos de corrupción. A pesar de la reglamentación dictada, la pastoral para con los moriscos podía difícilmente alcanzar su meta. Primero debido al importante número de moriscos asignados a los curas y capellanes. La inexistencia de beneficio anexado a estos cargos destinaba a esta tarea un personal de motivación diversa, destacándose, según el testimonio, clérigos y alguaciles de dudosa moralidad y mediocre nivel intelectual, que cohechaban a los artesanos y tenderos moriscos indisciplinados y establecían a veces un lucrativo negocio. Según el anónimo delator,

"los fiscales y curas... son culpa de sus delitos por lo que les toman y llevan ordinariamente, como lo ha hecho Bartolomé de Artiaga, viejo fiscal de los moriscos que oyen misa en San Blas... que entra áspero a reñirles el no ir a misa y unas veces le dan el palomino y otra la gallina, otra vez los cuatro y los ocho reales, lo cual hacen de muy buena gana porque son enemigos de Dios y huyen de su presencia... Y por no ser llevados delante de Dios con muy larga mano, sobornan a los fiscales y curas. Yo conocí cura [sic] que el día de Pascua de Resurrección amanecían en su casa treinta y cuarenta corderos y carneros los cuales le enviaban los moriscos por las disimulaciones y conocí fiscal de moriscos que confesaba que le valían más de cincuenta mil maravedíes cada año porque de los tenderos llevan ordinariamente los fiscales el carbón, aceite, sal, especias, fruta, verdura con que sustentan su casa y así los tenderos no van a misa como lo dirá Francisco de Acosta, procurador de esta audiencia, que en su collación de San Lorenzo echó bien de ver que ningún morisco tendero iba a misa... Y yo he topado al dicho Bartolomé de Artiaga cerca de la botica con un mozo con un vaso 
lleno de jarabes; y el víspera [sic] de Navidad pasada llegó el dicho Bartolomé de Artiaga con un mozo con tres espuertas grandes a casa de Luis Hernández, morisco, y se las hincharon de fruta y no contento con esto volvió de allí a un poco e hinchó ambas faltriqueras, y Catalina de Ávila, su mujer [del tendero morisco], visto la insolencia y sinrazón dijo a un cerrajero viejo que vive pared y muro de ella ¿no es mejor ir a misa que no dar mi hacienda a estos ladrones?"69.

Un testimonio preciso y elocuente que, a pesar de ser anónimo, da cuenta de las dificultades y lentitudes para realizar la obra de evangelización de los moriscos e ilustra la brecha existente entre las medidas decretadas y las realidades del terreno. Es probable que para atenuar las insuficiencias de la evangelización, el arzobispo don Rodrigo de Castro apelara cada vez más a los jesuitas, pues las cartas de la Compañía dan prueba, a partir de 1590, de una revitalización del apostolado para con esta minoría ${ }^{70}$.

La dimensión represiva dominó, así, claramente los sínodos y las disposiciones decretadas por los sucesivos arzobispos con el fin de favorecer la integración de los granadinos fueron muy tímidas, incluso cuando las impulsaban las autoridades civiles. Inmediatamente después de la rebelión de las Alpujarras, Felipe II, en sucesivas ocasiones, había manifestado el deseo que las faltas cometidas por moriscos no recayeran en sus descendientes si éstos estaban en baja edad en el momento del levantamiento. Según los edictos reales de 1572, los niños de rebeldes, menores de diez años en el momento de la guerra, no debían ser esclavizados sino que habían de ser colocados con honradas personas eclesiásticas o seculares, que los educarían en la fe, haciéndolos al mismo tiempo trabajar a su servicio hasta la edad de veinte años, edad a partir de la cual recobrarían su plena libertad ${ }^{71}$. Los niños de los moriscos libres también fueron el objeto de la encarecida solicitud de las autoridades puesto que el mismo edicto real pedía colocar a los que estaban en baja edad con clérigos; y las niñas con mujeres principales "para las criar y enseñar"72.

Siendo las jóvenes conciencias más maleables que las de los adultos se apostaba por una asimilación rápida que sería más ventajosa en un entorno cristianoviejo. Felipe II exigió en esa misma resolución de 1572 que los niños, además de ser instruidos en la fe cristiana, aprendieran a leer y escribir según modalidades que las autoridades de justicia definirían de acuerdo con los prelados y curas $^{73}$. Este interés por la educación de los niños tardó en concretarse

69. R.A.H., Jesuitas, Tomo 104, 9/3677 doc. n²2: Carta al Doctor Luciano de Negrón canónigo y arcediano de Sevilla, provisor sede vacante. Véase el apéndice 7.

70. F. de B. de MedinA, «La Compañía de Jesús y la minoría...», p. 113.

71. Orden dictada en Madrid el 20 de julio de 1572 y la del 6 octubre de 1572: A.G.S. Cám. Cast., leg. 2196, $\mathrm{f}^{\circ} \mathrm{s} / \mathrm{n}$ : La orden que se ha de tener para la vivienda de los moriscos del reino de Granada que se repartieron por estos reinos, $\mathrm{f}^{\circ} \mathrm{s} / \mathrm{n}$.

72. Ibídem.

73. Ibídem. 
en Sevilla: ni la constitución sinodal de 1572, ni la de 1586 se interesaron por la cuestión. Sólo en 1604, el arzobispo don Fernando Niño de Guevara se hizo eco de la voluntad real, exigiendo que se crearan escuelas sobre el modelo de las escuelas de la Doctrina Cristiana, donde además de una enseñanza religiosa, se les enseñaría a leer y escribir, siendo obligación de los padres enviar a sus niños y mantener el maestro de escuela. En efecto, "los niños en su educación y crianza deprenden y son mejor instruidos en lo que en adelante deben hacer y guardar para ser buenos cristianos y salvarse, y de lo que los moriscos con sus hijos hacen hay poca satisfacción" ${ }^{\prime 74}$.

Estas iniciativas venían a completar los actos reglamentarios destinados a destruir toda característica de pertenencia a la cultura islámica, rematando una larga serie de disposiciones reales que habían hecho de la posesión de todo texto en lengua árabe un delito sancionado por penas de galera y azotes. El objetivo era impedir que los moriscos pudieran acaparar escritos para ocultar obras religiosas, o cartas que facilitarían posibles conspiraciones y propiciar sobre todo la extinción de los rasgos culturales propios. Se les prohibía de la misma forma practicar su lengua en los espacios públicos como en casa con penas de galera o de esclavitud. En lo relativo a los otros aspectos de las prácticas culturales moriscas como los bailes, danzas y fiestas de origen islámico, las autoridades reales se limitaron a reiterar la prohibición de celebrarlos que ya había afectado a los moriscos en $1566^{75}$. La Iglesia siguió el mismo movimiento y prohibió toda manifestación cultural susceptible de infidelidad o de freno a la integración esperando "que desta manera olvidarán su lengua y costumbre que tenían"76. Pero tal vez más que las otras estas normas carecían de aplicación inmediata; de hecho diversos testimonios muestran a los moriscos celebrando sus fiestas y hablando su propia lengua en las Gradas y otras partes concurridas de Sevilla, despertando con este motivo, en periodos de tensiones, el temor a conspiraciones. Un grupo que seguía visto, hasta la hora de la expulsión, como una quinta columna y al que se le consideraba como inasimilable según varios testimonios ${ }^{77}$.

74. Constituciones del Arzobispado de Sevilla..., cap. XI, 58.

75. L. del Mármol Carvajal, Historia de la rebelión y castigo de los moriscos del reino de Granada, Madrid, Biblioteca de Autores Españoles, t. XXI, pp. 123-125.

76. Constituciones del Arzobispado de Sevilla..., p. 55.

77. Sobre la efervescencia en las comunidades andaluzas en 1577, véase B. VINCENT y A. DomínGUEZ ORTIZ, Historia..., p. 60. En 1580, por temor a una conspiración morisca se decreta el toque de queda: véase M. BOEGLIN, «Entre resistencia a la política...». En 1595, se prohíbe a los moriscos salir de sus casas mientras los ingleses saquean Cádiz, B. VINCENT y A. DomínguEZ ORTIZ, Historia..., p. 162; el 16 de mayo de 1600, “un aviso... decía que se querían levantar los moriscos de esta ciudad de Sevilla con los de Córdoba...el asistente... mandó echar bando que ninguna persona fuese osada a decir ni hacer mal a los moriscos": F. de ARIÑo, Sucesos de Sevilla, ed. de A. DOMínguez ORTIZ, Sevilla, 1993, p. 112; en 1602, una situación similar se reproduce: véase M. SERRANO Y SANZ, «Nuevos datos...», p. 119. 


\section{CONCLUSIÓN}

Si la mayoría de aquellas medidas habían sido decretadas al calor de la deportación de 1570, éstas pretendían acabar con la cuestión morisca que constituía un fracaso en el proceso de homogeneización religiosa de la Península. El objetivo esperado, en Sevilla como en el resto de las ciudades, era llegar cuanto antes a la división de los núcleos en abierta oposición con la sociedad cristiana. La integración no podía pasar sino a través de la convivencia con las poblaciones católicas y el abandono de los rasgos de pertenencia a la cultura de los antepasados. Una voluntad etnocidiaria por parte de la Corona que se percibía como necesaria para vencer las resistencias de la población morisca y permitir que el mensaje evangélico penetrase en aquellas conciencias consideradas como abierta y ferozmente opuestas a la fe de Cristo. En el marco de la monarquía confesional, la Iglesia aparecía como uno de los pilares en la política de control diseñada por la Corona, de una manera directa, haciendo del cura la piedra angular de la vigilancia de la población deportada. Las autoridades civiles, por su parte, encontraban en ella un sólido apoyo y disponían de un potente enlace en el seno de las comunidades de cristianos nuevos.

No obstante, aunque las distintas disposiciones persiguieran el control físico de la población y pretendieran limitar su crecimiento, su aplicación fue más bien limitada, o incluso voluntariamente soterrada por las autoridades civiles. Evidentemente, las elites veían en esta afluencia de exiliados una mano de obra barata, cualificada y poco vindicativa. Más que un elemento disuasorio, el aparato legal represivo hacía de cualquier morisco un delincuente potencial, un constante "contrabandista", expuesto en permanencia a repentinos cambios de estrategia de las autoridades o a inopinados controles que no podían sino reforzar la marginación social.

Desde luego, con los escasos medios movilizados, la evangelización de la población morisca sólo podía ser lenta, tanto más en una urbe como Sevilla donde la concentración de nuevamente convertidos procedentes de Granada era sumamente elevada, a los que se añadían los berberiscos y otras poblaciones de origen musulmán. A pesar de ello, en Sevilla como en el resto de Castilla, a la hora en que Felipe III decidiera zanjar la cuestión morisca de la forma más drástica y violenta, a través de la expulsión masiva, es preciso comprobar que la mayoría de ellos daban muestras de una integración creciente y ya no se manifestaba un rechazo masivo de la religión cristiana, sino entre aquellos que habían vivido y padecido los trastornos de la guerra y las condiciones horrendas de la masiva deportación a Sevilla, es decir, esencialmente en la primera generación de exiliados ${ }^{78}$.

78. Es por lo menos lo que revela el estudio de la edad y procedencia de los procesados: véase M. BOEGLIN, L'Inquisition espagnole au lendemain..., pp. 272-273. Para Cuenca, véanse las conclusiones de M. García Arenal, en La Inquisición y los moriscos. Los procesos del tribunal de Cuenca, Madrid, 1978, p. 177. Para Ávila, véase S. de TAPIA, «Los moriscos de Castilla la Vieja, ¿una identidad en proceso de disolución?», Sharq al-Andalus, 12 (1995), pp. 179-195. 


\section{APÉNDICE DOCUMENTAL}

Carta del conde de Priego, asistente de Sevilla al rey, del 15 de diciembre de 1570.

A.G.S. Cám. Cast., leg. 2157, fo 81: el conde de Priego al rey, 15/12/1570.

Como tengo escrito a V. Md, Don Sancho de Leyva llegó a esta ciudad a los veinte y siete del pasado ${ }^{79}$ con veinte y cuatro galeras y dellas se entregaron a mis oficiales quatro mill $\mathrm{y}$ trescientos moriscos tan destrozados y pobres y robados y enfermos que fue gran compasión, y los que no lo venían, tan flacos y hambrientos que, visto que morían muchos y padesçían tanta necesidad sin poder bastar las limosnas que se les dan de mala gana, me pareçió, por ser tanta gente y tener tan mal aparejo, de remediarla y disponer de muchos de ellos con la brevedad que convenía, puniendo los que se pudiese con amos y los enfermos a los [h]ospitales, así por su sustentación y reparo como por entender que dividiéndolos serían más aprovechados, a lo menos los niños, para la instruçión de la fe. Y ansí lo primero que hize fue mandar bautizar ad cautelan a todos los niños de dos años abajo y también por parecer que convenía por ser tantos y que hallavan acá compañía de los mismos, no dalles lugar a estar muchos juntos sino ansí divididos por poderse mejor remediar la necesidad que pasavan y por otros inconvenientes que consideré así por el entretenimiento de sus costumbres como por otros respectos y de todo ymbío relación con testimonio que va con ésta para que V. Md la mande ver si fuere servido.

Los lugares de la tierra están muy necesitados por la esterilidad del año y sigún esta gente venía enferma y desmedrada hallando mal aparejo en los lugares donde fueran me paresció menos ynconveniente dar algunas casas dellos a algunas personas para sus heredamientos y a otras para poblaciones a algunos lugarejos cercanos a esta ciudad y con esto me parece se a esparcido mucha cantidad dello y están de manera que todas las vezes que $\mathrm{V}$. Md. fuere servido darán cuenta dellos las personas a quien se les [h] an entregado por la orden que dicho tengo y entiendo que sigún mueren cada día muchos y no lo serán los que quedaren dellos, los quales se llevarán a las partes y lugares que V. M. manda por su carta del XXVII del pasado a que respondo con ésta. Guarde Nro. Señor y ensalce la S. C. R. persona de V. M. con grande acrecentamiento de reynos y tierras. De Sevilla y de diciembre, 15 de 1570.

De Vra. S. C. R. M. humilde criado y vasallo que sus reales pies y manos besa,

El Conde de Priego.

79. Los otros documentos señalan el 29 de noviembre 1570 como fecha de la llegada de las galeras. 
El teniente de asistente de Sevilla, 2 de enero de 1571, [al rey] sobre la relación que falta.

A.G.S. Cám. Cast., leg. 2159 f 2.

S. C. R. Mt.

Por ausencia del Conde de Priego Asistente de esta ciudad y como su teniente recebí una cédula de V. M. en que por ella manda envíe cierta relación sobre cómo se acomodarán mejor los moriscos que se han traído a esta ciudad así en ella como en los lugares de su tierra y comarca y, en cumplimiento de lo que V. M. Manda, digo que como el Asistente ha informado a V. M., él recibió por un ent[reg]o de Don Sancho de Leyva quatro myll y trezientos y tantos moriscos entre hombres, mujeres y niños y todos éstos vinieron destrozados y los más de ellos enfermos, mareados y el Asistente cumpliendo lo que V. M. le enbió a mandar por otra su real cédula repartió mill y trescientos dellos en lugares de Frexenal, Aracena, Constantina, Alanis, Cazalla y el Pedroso, tierra de Sevilla que son los más aparejados para poder los recibir y de los que aquí quedaron se pusieron con amos así labradores como officiales y ciudadanos mill y seiscientos para que los doctrinasen y trabajasen en sus oficios en esta ciudad y en algunos lugares comarcanos de ella. Todos los restantes quedaron enfermos de modorra y tabardetes y otras enfermedades muy malas que se comenzaron a pegar a los vezinos de esta ciudad con tanta furia que fue necessario para atajar tan grande mal, con consulta y parecer de médicos, que se sacasen luego a curar fuera de esta ciudad. Y assí se hizo por orden de ella y del Assistente y se pusieron en un hospital donde [h]ay [h]oy curándose seiscientos enfermos, sin otros más de cuatrocientos que están repartidos por la misma orden en otros [h]ospitales y se les dan las medicinas y mantenimientos necesarios. Tiénese por cierto, según la información que se ha hecho por las collaciones que son muertos aquí más de los mill de ellos y muy gran parte de los que se llevaron fuera, y de cada día se van muriendo y parece que, entre sanos y enfermos, están en esta ciudad hasta mil y seiscientos con mucho trabajo y pobreza. Y así, por esto como por sus enfermedades, no se podrán sacar de donde están hasta que convalezcan ni se puede tener certidumbre de los que quedarán vivos y libres de las enfermedades que tienen que, cuando lo estén, se podrán repartir algunos de ellos por las collaciones de esta ciudad que son veinte y cinco y los demás por los otros lugares de ella, adonde no se han llevado, que serán más de cincuenta, haziendo la mayor división dellos que sea posible para que mejor reciban la doctrina cristiana y trabajen en sus oficios poniéndoles graves penas para que dellos ni de la tierra no hagan falta ni ausencia. Esto es lo que agora ha passado y lo que adelante se podría hazer V. M. mande y provea lo que más a su real servicio convenga. Nro Sr la S. C. R. Persona de V. M. prospere y ensalce con acrecentamiento de más reinos y señoríos. De Sevilla, 2 de henero 1571 años.

\section{S. C. R. Mt.}

Besa humillmente los pies y manos de V. Mt su vasallo, El Licenciado Valera. 
Relación de los moriscos [deportados] que hay en Sevilla y su tierra del 9 de abril de 1571.

A.G.S. Cám. Cast., leg. 2162, fº 64.

\begin{tabular}{lcc}
\hline & NÚMERO DE CASAS & MORISCOS (1) \\
\hline Alanis & 36 & 50 \\
Aracena & 34 & 140 \\
Cazalla de la Sierra & 20 & 55 \\
Constantina & 50 & 57 \\
El Pedroso & 27 & 48 \\
Fregenal & 23 & 160 \\
San Bernardo (Sevilla extramuros) & 58 & 260 \\
Torregrosa & 14 & 44 \\
Triana & 306 & 1.494 \\
Total & 568 & 2.308 \\
\hline
\end{tabular}

(1) hombres, mujeres, niños

“... Por manera que son todas las dichas casas de los moriscos quinientos y sesenta y ocho casas y del número de los que parece que biben en ellas dos mil y trezientos y ocho moriscos y con los demás que están encomendados a servir a v[ecin]os de la d[ic]ha nuestra jurisdicción y comarca son a cumplim[ient]o de dos mill y ochocientos y sesenta moriscos poco más o menos y los que faltan son muertos y faltan del número que se registró de todos los moriscos que vinieron a esta ciudad, todo lo qual más largamente consta y parece por los dichos padrones, autos y diligencias que sobre ello se hicieron a que me refiero que quedan en poder del escrivano y en su escrito que es fecho en Sev[ill]a lunes nueve días del mes de abril de mill y quin[ient]os y setenta y un año. El Licenciado Valera...".

\section{4}

Carta del corregidor de Carmona, el licenciado Gutiérrez de Mayorga, del 27 de agosto de 1571.

A.G.S. Cám. Cast., leg. 2163, fo57-59.

Ill[ustr]e S[eñ]or.

Por una carta de su Mag.d referendada de V.M. se me manda ynbíe rel[aci]ón a V.M. de los moriscos que desta villa se [h]an ausentado y faltan y con qué licencias y, en cuplimiento dello, luego hize hazer junta y lista de todos los moriscos por pregón público y, a causa de que los moriscos andavan en el campo segando y en el trabajo de la cosecha del pan con los vecinos desta villa, no se pudieron juntar tan a tiempo quanto yo quisiera para poder hazer y inbiar la relación más presto y por esto [h]a [h]abido algunos días de dilación en ello. De las juntas y lista que se hizieron resultó la relación que con ésta va, signada del escribano de cabildo ante quien todo pasó. Yo, [h] a quatro meses que tomé las varas en este corregimiento y en mi tiempo no [h] a faltado ni se [h]a ido morisco ninguno ni yo he dado licencia ni la 
daré y haré la quenta y guarda con ellos que Su Majestad manda. Los que aquí residen son de diferentes partes como V.M. mandará ver por la relación y muchos de ellos son viejos y no pueden trabajar y padecen necesidad y los que tienen hedad para trabajar, salido el verano y cosecha del azeytuna, el otro tiempo no tienen a qué ganar y [h]an pedido algunos licencia para yr a trabajar a otras partes y como no [h] ay orden para dárseles, no se da y a esta causa pasan algunos trabajos y más por la esterilidad del año, que [h]ay gran falta de pan. Y éstos se podrían aprovechar en la comarca, especialmente en los lugares de la ribera del Guadalquivir adonde no [h]ay ningunos [sic] y allí podrían ganar de comer y trabajar por estar en ribera.

Guarde N[uest]ro Sr y prospere la Ill[ustr]e persona de V.M. con mayor acrecentamiento de estado. De Carmona y de agosto, 27 de 1571.

$$
\text { Ill[ustr]e S[eñ]or. }
$$

Besa las IIl[ustr]es manos de V.M.

El Licenciado G[utié]rrez de Mayorga.

"... Cuenta de los moriscos", Sevilla, 21 de junio de 1580.

A.G.S. Consejo Real 257 exp. 4, f 8 -I.

[1570] los moriscos que binyeron que se entregaron de las galeras fueron quatro myll y trescientos

los que se entregaron a vecinos de Sevilla y su tierra para admynystrarles conforme al bando novecientos y ocho.

los que parece que se llevaron a la tierra de Sevilla y se entregaron a los concejos son myll y dozientos treinta y tres

que montan estas dos partidas dos myll y ciento y quarenta e uno

que restados de los dhos quatro myll y trezientos quedaron enfermos y sanos, hombres, mujeres y nyños dos myll y ciento y cinquenta y nueve

[1580] los moriscos honbres mujeres y nyños que parece por los padrones que an hecho agora los jurados desta ciudad según la quenta de los dhos padrones montan seis myll y dozientos y quarenta y siete

los cautivos que ay destos según los dhos padrones son myll y ochenta y tres rrestan según esta quenta cinco myll y ciento y sesenta y quatro 
Carta de los jurados de Sevilla. 20 de abril de 1580.

Archivo Municipal de Sevilla, Sección XVI, Varios antiguos $n^{\circ} 334, f^{\circ} 2 r / v$.

20 de abril

Los jurados de esta ciudad dezimos que en nuestro cavildo hordinario que hizimos en sávado diez y nueve días del mes de março se acordó hazer saver a V. Sa como ya la consta el muncho número de moriscos que en esta ciudad hay, los quales tienen por costumbre de bibir en corrales y casas y otras partes juntos de tal manera que el menos número [sic] que se juntan dellos más de beynte, los quales biben con muncha libertad y desenboltura de tal manera que exercitan su ley, hablando su ley, cantares y algazaras [sic] y bibiendo libres sin servir a ningún señor. De lo qual a sucedido teniendo la dicha libertad andan de día y de noche con armas y an hecho muchos delitos ansí matando hombres como robándolos. Lo qual todo cesaría probeyendo V Sa que los tales moriscos horros sirvan a señores y los que no fueren para ello no biban de dos arriba en una casa y ésta sea entre cristianos viejos porque de bibir muchos y juntos y sin amos y con tanta libertad [h]an sucedido los delitos que [h]emos $\mathrm{d}[\mathrm{ic}]$ ho y los demás que a V. Sa le es notorio porque entre ellos los tratan e comunican para los hazer y perpetuar ansí en esta ciudad como en el campo.

Por todo lo qual pedimos suplicamos a V. $S^{a}$ en nonbre de esta república proveer lo que aquí pedimos pues tanto importa para el remedio della y asimismo $\mathrm{V} \mathrm{S}^{\mathrm{a}}$ pida al Señor Conde Asistente y a sus oficiales tengan gran cuidado de visitar los $\mathrm{d}[\mathrm{ic}]$ hos moriscos teniendo listas padrón dellos porque demás de mandallo y proveello ansí la premática de su M[aj]estad que es sobre esto habla se sirvirá Dios Nro Sr y esta república recibirá bien y merced y se excusarán grandes delitos que cada día suceden. Y de cómo lo pedimos y suplicamos a V. S ${ }^{a}$ lo pedimos por testimonio.

Andrés de Escalona. escribano.

\section{Carta anónima elevada al provisor de Sevilla.}

Real Academia de la Historia, Col. Jesuitas, Tomo 104, leg. 9/3677 exp. 22.

[Carta anónima y sin fecha. Puede fecharse entre 1580 y 1582, puesto que alude al gobierno anterior del arzobispo Cristóbal de Rojas fallecido en 1580, sustituido únicamente en 1582 por Rodrigo de Castro].

Al Doctor Luciano de Negrón canónigo y arc[edian]o de Sevilla, provisor sede vacante.

A los Señores prelados que an sido de esta silla y a sus provisores e dado avisos de cosas graves con qué descargarles sus conciencias y lo mismo haré en el tiempo que durare esta vacante pues soy tan servidor de VM, teniendo cuidado no le encarguen a VM la conciencia, especialmente en casos de moriscos y de clérigos disolutos.

En tiempos de Don Cristóbal le di aviso que los moriscos del reino de Granada vivían de por sí en corrales sin admitir cristiano viejo ninguno por causa de que no fuesen vistas ni entendidas las çanbras y ritos mahométicos que hacían y los delitos que cometían los moriscos el día que bautiçavan sus hijos porque, con agua caliente, les labavan y limpiavan las partes 
donde se les pone el olio. Esto se remedió con mandar que biviesen entre cristianos como ahora lo hacen, de donde resultó saberse y entenderse su mala vida y el descuido y mal tér[min]o de proceder de los fiscales y curas de ellos, que son culpa de sus delitos por lo que les toman y llevan hordinariamente, como lo a fecho Bartolomé de Artiaga, viejo fiscal de los moriscos que oyen misa en Sant Blas, como está probado en la causa que se a fecho contra Luis de la Cruz, Miguel su hijo y mujer y nuera, que entra áspero a reñirles el no yr a misa y unas veces le dan el palomino y otra la gallina, otra vez los cuatro y los ocho reales, lo qual hacen de muy buena gana porque son enemigos de Dios y huyen de su pres[enci]a. Se ha visto en San Marcos llevar Sama, cura que es un buen cristiano, y Antonio de Queto su fiscal, que anbos hacen el officio como deven, a un morisco a misa como ellos lo dirán y, al tiempo de alzar el Santísimo Sacramento, se vio que este morisco ponía el sombrero delante y metía la mano con una higa [sic] en el sombrero dándola al $S^{\mathrm{mo}}$ Sacramento, el qual fue servido que se entendiese su delito y fue llamado por los señores inquisidores y confesó sus pecados, fue açotado y echado en galeras. Y por no ser llevados delante de Dios con muy larga mano sobornan a los fiscales y curas. Yo conocí cura que el día de Pasqua de resurreçión amanecían en su cassa treinta y quarenta corderos y carneros los quales le ynbíavan los moriscos por las disimulaciones y conocí fiscal de moriscos que confesava que le valían más de cinquenta mil mrs cada año porque de los tenderos llevan hordinariamente los fiscales el carbón, aceyte, sal, especias, fruta, verdura con que sustentan su casa y así los tenderos no van a misa como lo dirá Francisco de Acosta, procurador de esta audiencia, que en su collación de San Lorenzo echó bien de ver que ningún morisco tendero yva a misa; y lo dirá el Vachiller Pedro Ponce, cura de Oniun Santorun [sic], hombre honrado y buen cristiano que es cura de los moriscos de San Lorenzo (...) y a querido muchas veces dar memoria de los que no van a misa. Y siguiendo el particular del dicho Bartolomé de Artiaga, fiscal, y del Ldo Alonso de Herrera, cura de sus moriscos, digo que en la collación de Oniun Santorun en la calle de Santo Antonio biven [sic] un sastre que le hace de vestir de valde y éste es disimulado por él y por su cura y no va a misa al ospital. Junto a la barrera de Alvar Negro viven dos boticarios, el primero se llama Agustín y es morisco: no va a misa con los otros moriscos ni lo a visto cristiano en la iglesia de los moriscos y yo e topado al dicho Bartolomé de Artiaga cerca de la botica con un moço con un vaso lleno de jarabes y el víspera de Navidad pasada llegó el dicho Bartolomé de Artiaga con un moço con tres espuertas grandes a casa de Luis Hernández, morisco, y se las yncheron de fruta y no contento con esto bolvió de allí a un poco e ynchó ambas faltriqueras, y Catalina de Avila, su mujer [del tendero morisco], bisto la insolencia y sin razón dijo a un cerrajero biejo que vive pared por medio de ella ¿no es mejor ir a misa que no dar mi hacienda a estos ladrones? Contra esta morisca y contra Luis Hernández, su marido, tengo hecha información que pende ante VM por donde consta ser malos cristianos, porque no sólo no van a misa pero estando heridos de landre despreciaron el S[antísi]mo Sacramento de la confesión yendo el cura Navarrete a confisarlos y no quisieron y se les murió en casa un morisco sin confisión que no quisieron llamar quien le confesase. Finalmente, por no yr a misa ni tratar de cosas de cristianos dan su hacienda de larga mano y es justo que los tales curas y tal fiscal no encargue la conciencia a su prelado que era. $Y$ un hombre cura de moriscos como es Sama y Antonio de Queto su fiscal que pueden juntar sus moriscos con los de San Blas y administrarlo [sic] an con cristiandad (...). 


\title{
RESUMEN
}

A finales de noviembre de 1570, se deportaban a Sevilla 4.300 moriscos procedentes de Granada en condiciones particularmente difíciles. De su llegada, resaltaban la inmensa confusión imperante así como la falta de preparación de las autoridades para recibir semejante número de desplazados. Si la política de diseminación de los núcleos se puso en obra rápidamente, Sevilla presenció en los años posteriores un incremento continuo de la población morisca en su seno, hasta los años 1580, en que se realizó uno de los primeros censos de la población deportada, que reveló la existencia de más de 6.000 moriscos en la capital, la mayoría de ellos asentados en violación de todos los bandos y pragmáticas reales. En el ámbito local, la Iglesia sevillana intervino al lado de las autoridades municipales y reales para controlar la población, suprimir los rasgos distintivos de la cultura morisca y forzar la asimilación. A pesar del imponente aparato represivo dictado para diluir la identidad morisca en medio de la sociedad cristianovieja, la aplicación de dichas normas fue muy relativa.

Palabras clave: moriscos, Sevilla, deportación, etnocidio, siglo XVI, convivencia, Iglesia, control.

\begin{abstract}
At the end of November of 1570, 4.300 moriscos "granadinos" were deported to Seville where they attracted the attention of the authorities. Their arrival, which comprised the only shipment of people to the sevillian capital resulted in widespread confusion and revelaed the lack of preparation of the authorities to receive this group of "rebelados". The policy of dispersing the group to the provinces was quickly put in place and resulted in a continuous increase of the moriscos in Sevilla, until 1580, when one of the first census of the deported population was made. It confirmed that more than 6.000 were in the town with more than half having flouted the royal bans forbidding their settlement. In the local area, the Sevilian church intervened with municipal and national authorities to control this population of "cristianos nuevos" and to wipe out their distinguishing characteristics by forcing them to assimilate to Castilan society. Nevertheless, application of these norms was very relative.
\end{abstract}

Key words: moriscos, Seville, deportation, ethnocid, 16th century, coexistence, Church, control. 